Article

\title{
Does Technological Innovation Drive Corporate Sustainability? Empirical Evidence for the European Financial Industry in Catching-Up and Central and Eastern Europe Countries
}

\author{
Francisca Sempere-Ripoll ${ }^{1}$, Sofia Estelles-Miguel ${ }^{1, *}$, Ronald Rojas-Alvarado ${ }^{2,3}$ and \\ Jose-Luis Hervas-Oliver ${ }^{1,4,5}$ \\ 1 Management Department, Universitat Politècnica de València, 46022 València, Spain; fsempere@omp.upv.es \\ 2 Gestión Organizacional, Universidad ICESI, Cl. 18 \#122-135, Cali 760032, Colombia; \\ ronald.rojas@correo.icesi.edu.co \\ 3 Escuela de Ciencias Básicas, Tecnología e Ingeniería, Universidad Universidad Nacional Abierta y a \\ Distancia, Bogota 110111, Colombia \\ 4 Unidad Permanente de Investigación, ESIC Business \& Marketing School, 28223 Madrid, Spain; \\ Jose.hervas@omp.upv.es \\ 5 Industrial Engineering Department, Universidad de la Costa, Cl. 58 \#\#55-66, Barraquilla 080001, Colombia \\ * Correspondence: soesmi@omp.upv.es
}

Received: 28 January 2020; Accepted: 6 March 2020; Published: 13 March 2020

\begin{abstract}
In the financial industry, two relationships are well-researched: (i) innovation and financial performance and, (ii) sustainability and financial performance, both focused primarily on Western and advanced countries. The relationship between innovation and sustainability, however, is underresearched. This study's purpose consists of determining whether there is a relationship between innovation and corporate sustainability in the financial industry. In doing so, this study responds to a critical question: are the most innovative firms also the most sustainability-oriented? We empirically explore sustainability-oriented innovation in the financial industry of 11 catching-up countries in Central and Eastern Europe (CEE). Using Community Innovation Survey (CIS) data for 2012-2014, this study empirically analyzes a large sample of 1574 firms in the financial industry. Our results suggest that innovation is positively linked to corporate sustainability, pointing out that innovation capabilities are positively related to sustainability. Our study proposes a framework for analyzing innovation and sustainability from a capability-perspective.
\end{abstract}

Keywords: innovation; financial industry; sustainability; Central and Eastern Europe; CIS data

\section{Introduction}

In the financial industry, the sustainability-oriented innovation topic is underresearched [1] and constitutes this study's goal. Innovation in the financial industry, on the one hand, is a key topic well-researched by scholars [2,3], especially referring to digitalization of banking [4]. In this study, innovation is defined as a new or significantly improved product (good or service) introduced to the market or the introduction within an enterprise of a new or significantly improved process (see Eurostat).

Sustainability, on the other hand, integrates environmental and social performance with economic business performance [5]. We address sustainability with a very broad view, in line with the stakeholder theory [6], addressing all different stakeholders such as government, local communities, customers, employees or the environment, referring to sustainability as a way of meeting different stakeholders' 
interests. Sustainability in the financial industry presents a small but growing body of evidence, especially that linking corporate social responsibility (CSR) and financial performance [7-9].

Despite both topics being well-researched in the financial industry, they are tackled in isolation from each other, rarely being analyzed simultaneously. The link between innovation and sustainability in the financial industry, therefore, is under-researched [10], Forcadell et al. [1] and Yip and Bocken [11] being the only two recent and remarkable pioneering exceptions focused on Western countries [3] and the Hong-Kong financial industry [11], respectively. Why is sustainability-oriented innovation in the financial industry so under-researched? The financial industry is assumed to have a limited direct environmental impact [1], as it is not a manufacturing industry related to global warming, waste or the carbon footprint. As Yip and Bocken [11] point out, nevertheless, financial industry presents a very important impact on sustainability, broadly in all its dimensions of governance, environment and social terms. New possibilities include maximizing material and energy efficiency, substituting with digital processes, promoting sensible borrowing, supporting social enterprises, re-employing retired staff on contract basis, employing physically disabled persons and encouraging staff to do volunteer work by giving paid leave, reducing fees for nongovernmental organizations (NGOs), promoting green bonds or just promoting social innovation. The possibilities are enormous and no less important than opportunities generated in other industries. The topic, therefore, constitutes a promising research avenue that is tackled in this present study. This study attempts to contribute to filling this gap by providing a very ample empirical exercise on that relationship.

In addition, it is observed that most of the literature on sustainability in the financial industry, even though it is not related to innovation but to financial performance, is oriented to Western countries, being almost absent in Central and East Europe Countries (CEEC), as compared to developed countries and, therefore, more research in this field is also needed [12]. In fact, sustainability is said to significantly differ between Western and CEE countries (e.g., [13]) and sustainability studies in CEEC are scarce [12]. Countries from CEE are called catching-up or technology followers, using Castellacci's and Archiburgi's [14] term, those with relatively medium-high per capita incomes and relatively well-developed institutions, such as those from CEE countries.

Thus, our study is contextualized at the intersection of the literature on sustainability-oriented innovation $[10,15-17]$ in the financial industry [10] and in the particular case of catching-up and CEE countries that require further investigation on the topic [12]. This study's goal, therefore, consists of determining whether there is a relationship between innovation and corporate sustainability in the financial industry of catching-up and CEE countries, an exercise not yet accomplished. This present study, therefore, is the first undertaking of that approach.

In this context, we test whether innovation leads to an improved corporate sustainability orientation in the financial industry, presenting a capability framework based on the resource-based view of the firm (e.g., [18]) and the dynamic capabilities [19] from which to address innovation and the corporate sustainability performance relationship.

Theoretically, our central hypothesis states that innovation is positively linked to corporate sustainability. Empirically, we assess the relationship between innovation strategies and sustainability performance in 1574 firms in the financial industry for the period 2012-2014, using Community Innovation Survey (CIS) data for 11 catching-up and CEE countries. CIS data allows us to consider simultaneously sustainability-oriented innovations in CEE countries, presenting an opportunity to study both innovation and sustainability simultaneously. Methodologically, we utilize Ordinary Least Squares (OLS) regressions, along with factor analysis and ANOVA tests to sustain the analysis of data. The results show that a firm's innovation intensity is positively related to corporate sustainability. This study contributes to providing insights on innovation and sustainability in the financial industry in catching-up and CEE countries, by showing that their firms are not very innovative, nor sustainability oriented; the firms that invest more in innovation, however, can achieve better sustainability-oriented aims. In particular, the building up process and organizational innovation capabilities reinforce 
sustainability orientation. These results present interesting implications for managers in the financial industry in CEE countries, scholars and policymakers.

The structure of the paper is as follows. Section 2 presents a framework from which to address innovation and sustainability. Then, Section 3 shows the empirical design, Section 4 presents the findings, and that is followed in Section 5 by conclusions and suggestions for future lines of research.

\section{Theory}

\subsection{Sustainability and Financial Performance in the Financial Industry}

Corporate sustainability is often associated with environmental, social and governance components [20,21], aiming at creating positive benefits and reducing negative ones to the environment, society and other stakeholders [22]. Corporate sustainability balances environmental and social performance with economic performance [5], with the aim of meeting different stakeholders' interests and not focusing only on financial profit. In this study, as aforementioned, we adopt a comprehensive approach to sustainability in line with the stakeholder theory [6], considering a large audience of stakeholders such as government, environment, customers, employees, local communities and others.

General literature, on the one hand, has intensively focused on the relationship between CSR and financial performance, pointing out a huge heterogeneity of results, depending on the sample utilized and the country of study (e.g., [12,17,23-25]). In this chain of thought, Luo and Du [26] empirically encounter that analysts reduce information asymmetry related to CSR between firms and in this way, firms gain visibility by being recognized as best-in-class. Awaysheh et al. [17] find that best-in-class firms in CSR do receive higher relative market valuations than industry peers. CSR and its relationship with financial performance, however, is fuzzy, as there are also diverse studies that do not show that positive relationship (e.g., [27]). Results, therefore, are inconclusive (e.g., [28]).

As regards sustainability and financial performance in the financial industry, on the other hand, literature is scarce and it has similarly produced inconclusive results (e.g., [8]), with both positive [29] and negative outcomes [30], in line with the blurred evidence on other industries pointed out above (e.g., [28,31]). For instance, Esteban-Sanchez et al. [9] find a partially positive relationship from the employees and community dimensions but not from the governance one in the period of the financial crisis; specifically, they find that during the crisis the banks with better relations with the community could be valued positively by investors, which, in turn, increases corporate financial performance. Despite the influence of banking in society [32], the participation of the banking industry in nonsocially responsible practices is widely recognized [33], especially during the recent financial crisis [9], due to subprime mortgages and other toxic products, even though the banking sector was among the first industries to implement CSR programs.

\subsection{Going Further: Sustainability-Oriented Innovation}

Beyond the debate of CSR, sustainability and financial performance discussed above, when addressing innovation and sustainability relationship, following De Marchi [34], sustainable innovation oriented to the environment may be defined as new or modified processes, techniques, practices, systems and products to avoid or reduce environmental harm [35]. The definition presented is operational for diverse specific targets such as waste management, eco-efficiency, reduction of emissions, recycling, eco-design or any other action implemented by firms to reduce their environmental footprint. Does innovation capability also lead to corporate sustainability performance? According to evidence, innovation drives environmental performance, albeit this literature has been tested only in manufacturing sectors or eco-innovations. As such, open innovation or external collaboration to innovate is found to improve environmental innovation [34]. Similarly, developing internal technological capabilities by investing in R\&D also triggers environmental innovations [27,36]. Addressing jointly both the internal and the external drivers of innovation, Cainelli et al. [16] found for Spanish manufacturing firms that it is very important to comprehensively invest in external 
factors triggering environmental innovations and complement them with those of the internal resources the firm has access to in order to fully understand and support the development of environmental innovations. In the same chain of thought, qualitative evidence has also suggested the critical role of networking, and sourcing external sources of knowledge, with external actors (universities and public research centers) to improve cooperation and environmental innovation (e.g., [37]). These studies linking innovation and sustainability, however, are systematically performed across industrial or manufacturing sectors, omitting the financial or banking industry and even the service industries.

Despite the above argument about sustainability-oriented innovation, this study' goal is focused on the financial industry. Put differently, the goal is beyond the linkage between CSR and financial performance or innovation studies in manufacturing industries; our central question is different yet related: is innovation related to sustainability in the financial industry? The answer is yes: innovation is the leverage that permits not only the creation of new value and innovative performance but is also directly and positively related to improved sustainability dimensions and other sustainability-oriented measures, such as CSR. In the particular case of the financial industry (e.g., [29,38]), the relationship between innovation and sustainability is said to be positive, albeit to the best of our knowledge there are only two studies, so further research is required. As stated by Forcadell et al. [1], innovation can improve corporate sustainability on many fronts, such as new digital requirements, customer demand and also financial performance. Similarly, in the specific case of the financial industry, Yip and Bocken [11] show how doing good is related to doing well in the bank industry of Hong-Kong while empirically evidencing how customers prefer those banks adopting sustainable business models. The problem, however, is that evidence is very scarce and limited to two papers, and the CEE countries are omitted from the analysis.

\subsection{CEE Countries, Innovation and Sustainability: What Do We Know?}

Literature on innovation in technology-follower countries or catching-up ones $[14,39,40]$ is relatively small (European Commission): in fact, most research on innovation is devoted to industrialized and advanced countries such as the UK (e.g., [41]), Italy (e.g., [42]), Spain (e.g., [41,43]), Germany (e.g., [44,45]) or Sweden (e.g., [46,47]), among many others.

Catching-up and CEE countries show lower innovation capacity that reflects a lower set of institutional and technological skills and capabilities managed and developed over time in their systems. To a certain extent, these countries present thin or not well endowed innovation systems, as is the case of most catching-up and CEE countries [48].

When addressing sustainability in these catching-up countries, as stated by Dyduch and Krasodomska [49], the variables determining corporate social-environmental performance in CEE countries are still relatively unknown, in no small part due to the lack of studies or those few addressing the financial industry of CEE countries, like Fijalkowska et al. [12]. On the whole, these countries present different contextual specificities, such as industrial norms, institutions or governmental policies, etc., that influence how their firms understand sustainability features (e.g., [50], as stated by Fijalkowska et al. [12]. CEE countries' interest in sustainability is moderated by their different institutions (formal and informal rules of the game), dynamic environment with systematic changes from rapid economic development, a preference for materialism and maximization of economic and financial goals and less emphasis on social issues.

Fijalkowska et al.'s [12] seminal study points out that finding financial industry from CEE countries presents no link between sustainability and financial performance, that is, sustainability engagement is not rewarded in these countries because their markets are not able to perceive social-environmental performance as a competitive advantage but rather as additional costs decreasing profitability in the financial industry. This result is coincident with that of Furrer et al. [13] that shows that attitudes toward social, economic and environmental corporate responsibility found in managers and students in CEE countries are less important, compared to the Western counterparts that accord more importance to sustainability, even though CEE countries are not homogeneous. All in all, in CEE countries, there is 
no study linking innovation and sustainability in the financial industry, and the present study is the first to do it.

\subsection{Innovation and Sustainability: A Capability-Based Perspective}

Our study is based on the relationship between innovation and corporate sustainability, specifically considering that firms introduce internal and source external routines and activities to develop knowledge from which to sustain the innovation process. This learning process enables the configuration of firms' capabilities to innovate. Both theories, the RBV (resource-based view of the firm, [18]) and the dynamic capabilities [19] constitute a general related framework to understand how firms design, develop and reconfigure capabilities to innovate. These capabilities are built from the combination of internal and external sources of knowledge [51]. Our reasoning is developed upon the RBV (e.g., [52]). RBV constitutes a useful framework from which to understand firms' innovation capabilities (human resources, organizational, know-how, patents, technological and others), competitive advantage and performance. This literature sustains that internal sources of knowledge (R\&D, human resources, routines, know-how, etc.) and external ones (sources of knowledge from the acquisition of embodied knowledge, cooperation with suppliers or universities, among others, also called open innovation by different scholars, (see [53-55]) configure the set of innovation capabilities that underpin competitive advantage and drive performance (see [56]). Thus, the virtuous cycle of the innovation capability is based on the firms' ability to identify, access and assimilate and exploit external knowledge, configuring the innovation capability by the joint reinforcing mechanism of both, internal and external sources of knowledge [53].

Accessing these external sources of knowledge requires investing in absorptive capacity [53], such as in-house capabilities to innovation being a precondition to access external sources for innovation [54]. A firm's external knowledge sourcing indicates how firms build their search strategy in order to access different types of external (to the firm) knowledge, such as suppliers, science or technology customers or consultants (e.g., [42]). In this line of thought, search strategies to access to external sources of knowledge for capabilities development and reconfiguration cannot be understood in isolation from firms' internal capabilities to innovate $[42,55]$, as firms structure their innovation capability by combining coherently both internal and external sources of knowledge to innovate.

The integration of different internal and external sources of knowledge facilitates the creation of unique capabilities from synergistic and complex interrelationships difficult to imitate, contributing thus to improving a firm's competitive advantage, producing inimitable systems that improve one another and create a unique configuration of knowledge that sustains and develops innovation capabilities [56-58]. In this line of thought, in this study we refer to innovation capability as the combination of both internal and external sources of knowledge that are structured and combined to pursue innovation. Empirical evidence has extensively shown how the combination of internal and external sources of knowledge to improve innovation capabilities also leads to innovative performance $[42,43,51,59,60]$.

Similarly, sustainability-oriented innovation literature point outs that firms' innovation capabilities influence sustainability $[35,54]$. Specifically, the innovation capability built upon internal and external sources of knowledge to innovate is proved to be linked to sustainability-oriented performance (e.g., $[16,34,60])$, evidence limited to the manufacturing sector. Therefore, pulling all the existing evidence together, we posit that the learning process of the innovation function is based on a combination of internal and external sources of knowledge that allow the formation and development of capabilities and the creation of positive synergies (e.g., $[51,61]$ ) to construct a firm's capability to innovate. These unique capabilities can also drive sustainability. Literature has connected innovation capability from internal and external sources of knowledge to sustainability-oriented innovation (e.g., $[17,34])$ and to the financial and banking industry [1]. Sustainability-oriented innovation can also be part of a firm's innovation capability, albeit different scholars claim that sustainability-oriented innovation capability is more "complex and sophisticated" [62]. 
Our main findings, as shown below, are summarized as follows: first, innovation capabilities for process and organizational innovations positively drive sustainability-oriented objectives; second, even though companies in the financial industry in catching-up and CEE countries are not very innovative, nor sustainability oriented, the firms that invest more in innovation can achieve better sustainability-oriented aims. In particular, building up process and organizational innovation capabilities reinforce sustainability orientation.

\section{Methods and Empirics}

\subsection{Hypothesis, Data Sourcing and Sample}

Overall, and in light of the reviewed literature (e.g., [1,17]), we expect that a firm's innovation capability, understood as its commitment of resources and investments in internal and external activities and knowledge to build up innovation capabilities, is also positively related to corporate sustainability. In this vein, the following hypothesis is stated:

\section{Hypothesis 1. A Firm's Innovation Capability is Positively Related to Corporate Sustainability.}

Innovation, on the one hand, is defined as a new or significantly improved product (goods or service) introduced to the market or the introduction within an enterprise of a new or significantly improved process. From this definition, innovation accounts for different approaches such as technological and nontechnological (marketing and organization) (see Eurostat, https://ec.europa. eu/eurostat/statistics-explained/index.php/Glossary:Innovation). Data were drawn from the CIS, aggregated by Eurostat, covering 2012-2014 on a pool-data basis. The CIS is extensively used in the UK, France, Spain, Italy, Germany, Portugal and Belgium, among other countries (e.g., [42,63]. The Community Innovation Survey is based on a standard core questionnaire developed by the European Commission (Eurostat) and Member States to ensure international comparability, encompassing both manufacturing and services. CIS data offer a direct measure of success in commercializing innovations for a broad range of industries that other sources of information do not capture [64]. Firms are in fact asked about the type of innovation introduced over the three-year period covered by every survey wave (annually) and the specific innovation activities carried out in the same period (innovation effects, investments in R\&D, patents, external sources of innovation, etc.), all of them associated with the innovation process. Despite not being sufficiently analyzed, catching-up and CEE countries are included in the CIS survey and gradually they are providing key information on the innovation process that requires analysis. The CIS is extensively used in empirical papers on innovation (e.g., [41,43,65]) and even in sustainability [34]. The CIS data is presented in waves of three years, being that the questions referred to different points in time or the entire period and conceptualized (for instance, as drivers or effects) in order to allow cause-and-effect or relationship. CIS data is not available in panel sets. A very interesting point of the 2012-2014 period is that it includes sustainability-oriented questions related to the innovation process that constitute the cornerstone of this study, especially because it was the first time that CEE countries were included in their respective surveys.

The financial industry is also chosen because of its especial influence on sustainability. The financial industry is positively driving economic development [65] because of their allocation process of resources to different sectors and firms strengthening development. In addition, the financial industry promotes the adoption of sustainable practices by potential borrowers, thus exerting a positive impact on sustainable growth [61]. This makes the financial sector unique when considering sustainability. In total, 1574 financial firms were in the data set for the financial industry in the CEE countries in the studied (2012-2014) period. These firms belong to the financial sector, reflected in the industry code NACE-64 (financial service activities, except insurance and pension funding) and NACE-66 (activities auxiliary to financial services and insurance activities) of the European industry standard classification system (NACE) across 11 countries. Our sample encompasses catching-up and CEE countries in Europe, and the number of firms in each are the following (including Greece and Cyprus, 
both catching-up countries in Europe): Bulgaria (346), Cyprus (124), Czech Republic (156), Estonia (72), Greece (73), Croatia (91), Hungary (208), Lithuania (105), Latvia (67), Romania (281) and Slovakia (51). We assume that this wide sample constitutes a very representative sample of those catching-up and CEE countries in the financial industry for our research purposes. See Table 1 for the sample.

Table 1. Distribution of firms by country.

\begin{tabular}{cccc}
\hline & CEE Countries & $\mathbf{N}$ & $\mathbf{\%}$ \\
\hline BG & Bulgaria & 346 & 21.98 \\
\hline CY & Cyprus & 124 & 7.88 \\
\hline CZ & Czech Republic & 156 & 9.91 \\
\hline EE & Estonia & 72 & 4.57 \\
\hline EL & Greece & 73 & 4.64 \\
\hline HR & Croatia & 91 & 5.78 \\
\hline HU & Hungary & 208 & 13.21 \\
\hline LT & Lithuania & 105 & 6.67 \\
\hline LV & Latvia & 67 & 4.26 \\
\hline RO & Romania & 281 & 17.85 \\
\hline SK & Slovakia & 51 & 3.24 \\
\hline & & 1574 & $100 \%$ \\
\hline
\end{tabular}

Source: own.

\subsection{Dependent Variables}

We define innovation in similar ways to the definition used in well-known existing studies $[16,34,35]$. This study uses the variable SUSTAINABILITY (sustainability-oriented factors) as a composite indicator that embraces all different measures of corporate sustainability, encompassing different indicators measured from 0 to 3 (none (0), low (1), medium (2), high (3)) such as:

- Improving the enterprise's reputation.

- Accessing government grants, subsidies or other financial incentives for environmental innovations.

- Reduction of the high cost of energy, water or materials.

- Compliance with existing environmental regulations.

- Meeting current or expected market demand for environmental innovations.

- $\quad$ Reducing existing environmental taxes, charges or fees.

- Environmental regulations or taxes expected in the future.

- Need to meet requirements for public procurement contracts.

- Voluntary actions or initiatives for environmental good practice within the sector.

Factor analysis also facilitates the reduction of a large number of variables into fewer numbers of factors, for both the dependent variable (sustainability) and the external sources variables (openness). This technique extracts maximum common variance from all variables and puts them into a common score. As an index of all variables, we can use this score for further analysis, specifically in the OLS regression. Using the above variables of corporate sustainability, within the construct SUSTAINABILITY, we construct a single indicator by applying a factor analysis (factor: $72.65 \%$ explained variance; KMO $=0.9153 ;$ Cronbach's Alpha $=0.96$. 


\subsection{Independent Variables}

As independent variables, reflecting the firms' innovation capability we utilize the four types of innovation defined by Eurostat and the Oslo Manual. These are the key variables capturing innovation capacity of firms. INNO_PROD indicates whether the enterprise introduced new or significantly improved goods or services; INNO_PROC indicates whether the enterprise implemented a new or significantly improved method for the manufacture or production of goods or services, logistics systems or delivery or distribution methods for its supplies, goods or services and/or support activities for its processes, such as systems of maintenance or IT operations, of purchases or of accounting, being new or significantly improved; INNO_ORG indicates if the enterprise introduced a new or improved organizational change during the research period.

INNO_MARK indicates if the enterprise introduced changes to marketing concepts or strategies during the research period. We also include external knowledge sourcing over the last 3 years (2012-2014) as regular interactions (External Sources variables) with Other firms in the group, Customers, Suppliers, Competitors, Consultants, Universities and Research Centers, adding them all up to one single indicator named OPENNESS, ranging from 0 to 7 (Cronbach's alpha: 0.807). This variable shows the intensity of the external knowledge accessed.

We also added other control variables, such as R\&D_INTERNAL, which captures a firm's investment in in-house research and development. In addition, as other studies indicated (e.g., [16,38]), external sources of knowledge capture the open innovation activity. Furthermore, other variables count as controls for the type of innovation (whether radical or not, RADICAL variable). Then, SIZE, is measured as the total number of employees, and countries are used as dummies (COUNTRY_DUMMIES variable) to control the sample. See Table 2.

Table 2. Description and codification of variables.

\begin{tabular}{|c|c|c|}
\hline Dependent Variables & Description & Codification \\
\hline $\begin{array}{l}\text { Sustainability oriented } \\
\text { factors (SUSTAINABILITY) }\end{array}$ & $\begin{array}{l}\text { Factor analysis of the following items: } \\
-\quad \text { Improving the enterprise's reputation } \\
\text { - Government grants, subsidies or other financial incentives } \\
\text { for environmental innovations } \\
-\quad \text { Reduction of the high cost of energy, water or materials } \\
-\quad \text { Compliance with existing environmental regulations } \\
-\quad \text { Meeting current or expected market demand for } \\
\text { environmental innovations } \\
-\quad \text { Reducing existing environmental taxes, charges or fees } \\
-\quad \text { Environmental regulations or taxes expected in the future } \\
-\quad \text { Need to meet requirements for public procurement contracts } \\
-\quad \text { Voluntary actions or initiatives for environmental good } \\
\text { practice within the sector } \\
\text { Each item is measured in the questionnaire as Likert-scale: } 0: \\
\text { Not important, } 1: \text { Low; } 2: \text { Med; } 3: \text { High importance } \\
\text { Factor analysis: } 72.65 \% \text { of explained variance; KMO }=0.9153 \\
\text { (Cronbach's Alpha }=0.96 \text { ) }\end{array}$ & $\begin{array}{l}0-3 \text { scale and } \\
\text { Factor variable } \\
\text { (continuous) }\end{array}$ \\
\hline Independent Variables & Description & Codification \\
\hline INNO_PROD & $\begin{array}{l}\text { Indicates whether the enterprise has introduced new or } \\
\text { significantly improved goods or services }\end{array}$ & $0-1$ \\
\hline INNO_PROC & $\begin{array}{l}\text { Indicates whether the enterprise has implemented a new or } \\
\text { significantly improved method for the manufacture or } \\
\text { production of goods or services, logistics systems or delivery or } \\
\text { distribution methods for its supplies, goods or services and/or } \\
\text { support activities for its processes, such as systems of } \\
\text { maintenance or IT operations, of purchases or of accounting, } \\
\text { being new or significantly improved }\end{array}$ & $0-1$ \\
\hline INNO_ORG & $\begin{array}{l}\text { Indicates if the enterprise has introduced a new or improved } \\
\text { organizational change during the research period }\end{array}$ & $0-1$ \\
\hline
\end{tabular}


Table 2. Cont.

\begin{tabular}{|c|c|c|}
\hline Dependent Variables & Description & Codification \\
\hline INNO_MARK & $\begin{array}{l}\text { Indicates if the enterprise has introduced changes to marketing } \\
\text { concepts or strategies during the research period }\end{array}$ & $0-1$ \\
\hline OPENNESS & $\begin{array}{l}\text { It is a measure of the number of agents with whom the firm } \\
\text { cooperates for product and/or process innovation. The } \\
\text { considered agents are the following: } \\
- \text { Other enterprises within enterprise group } \\
-\quad \text { Suppliers of equipment } \\
-\quad \text { Clients or customers from the private/public sector } \\
-\quad \text { Competitors or other enterprises } \\
-\quad \text { Consultants and commercial laboratories } \\
-\quad \text { Universities or other centers of higher education } \\
-\quad \text { Government, public or private research institutes } \\
\text { Each item is measured in the questionnaire as a dummy variable } \\
\text { and has a value of } 1 \text { if the enterprise cooperated with the agent } \\
\text { and } 0 \text { otherwise (Cronbach's alpha: } 0.807 \text { ) }\end{array}$ & Scale $0-7$ \\
\hline Control & Description & Codification \\
\hline R\&D_INTERNAL & Engagement in intramural $R \& D$ & Dummy 0-1 \\
\hline INNO_RADICAL & $\begin{array}{l}\text { Indicates whether the enterprise has introduced new or } \\
\text { significantly improved goods or services in the market before } \\
\text { the competitors }\end{array}$ & Dummy 0-1 \\
\hline SIZE & $\begin{array}{l}\text { Number of employees classified into three groups: } \\
\text { 1; SMALL: less than } 50 \\
\text { 2; MEDIUM: between } 50 \text { and } 250 \text { employees } \\
\text { 3; LARGE: more than } 250 \text { employees }\end{array}$ & Scale $1-3$ \\
\hline COUNTRY_DUMMIES & $\begin{array}{l}\text { Country dummies for each of the countries: Bulgaria; Cyprus; } \\
\text { Czech Republic; Estonia; Greece; Croatia; Hungary; Lithuania; } \\
\text { Latvia; Romania; Slovakia }\end{array}$ & Dummy 0-1 \\
\hline
\end{tabular}

\section{Results}

After the factor analysis explained above, we proceed methodologically by carrying out different analyses such as descriptive statistics, ANOVA tests and OLS regressions. First, descriptive statistics help us to understand the sample and its main indicators (means and standard deviations). Then, ANOVA tests and correlation matrix support the bivariate analysis of pairs of variables. With ANOVA tests we can start to explore whether innovative (versus noninnovative) firms are more (or less) sustainability-oriented or whether innovative (versus noninnovative) firms are more (or less) open to search external sources of knowledge. Finally, OLS regressions (in a total of 6 models or specifications) allow us to test the dependent variable as a linear function of a set of independent variables by the principle of ordinary least squares.

\subsection{Descriptive and Bivariate Results}

In this section the descriptive analysis and ANOVA tests are shown, along the matrix of correlations. As shown in Figure 1, in general, it is observed that firms in the financial industry of CEE countries are not oriented to sustainability or at least they engage poorly. In terms of measuring sustainability-oriented goals, on the one hand, statistics reveal that only $7 \%$ of firms (110 out of 1574) engage in "improving the enterprise's reputation" sustainability-oriented goal. The next goals are "voluntary actions or initiatives for environmental good practice within the sector" (6.6\%, 105 firms) and seeking to reduce "high cost of energy, water or materials" (5.7\%, 91 firms). The rest of the goals are even lower. Engagement in sustainability by the financial industry in CEE, therefore, is represented by a relatively low number of firms. See Figure 1. Figure 1 shows the percentage of firms that consider seeking each objective measure as any kind of influence (low, medium, high) in driving the enterprise's decisions to introduce innovations with sustainability benefits. This result is totally in line with that from Fijalkowska et al. [12] 
which points out the low recognition of sustainability in the financial industry in CEE countries. See Figure 1.

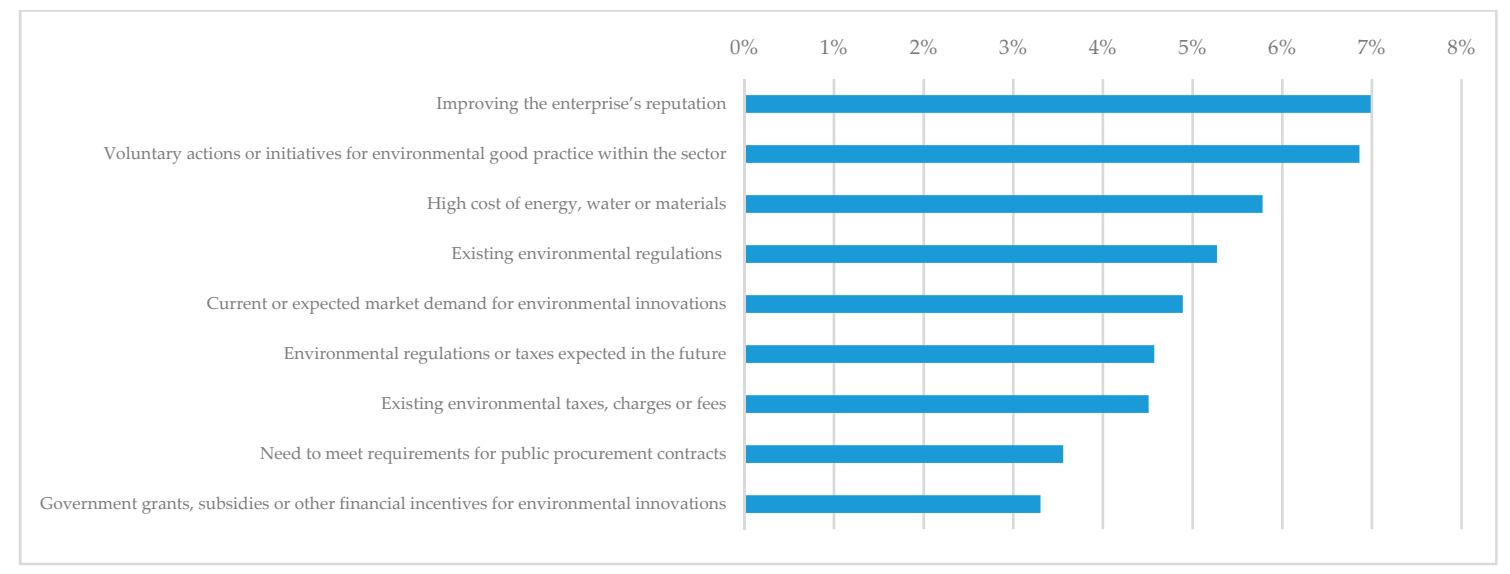

Figure 1. \% of firms that consider that each sustainability-oriented factor is of interest to them (low, medium, high) in driving the enterprise's decisions to introduce innovations with sustainability benefits. Source: own.

Therefore, innovation in the financial industry in CEE countries is relatively higher than the sustainability orientation. As is reported in Table 3, the averages are: product (19.88\%), process $(19.18 \%)$, organizational $(25.15 \%)$ and marketing $(23.63 \%)$. Overall, we observe innovation activity in $36.9 \%$ (581) of firms in the financial industry of CEEC. These figures, nevertheless, are very low for the Western standard (e.g., 64\% of German firms show innovative activities, on average of all industries or the $68 \%$ of Belgium) but are perfectly normal for CEEC standards. From EUROSAT data, innovation in CEEC varies from $48 \%$ in Estonia to $22 \%$ in Poland and $10 \%$ in Romania (see https://ec.europa.eu/eurostat/web/products-eurostat-news/-/DDN-20190312-1). R\&D expenditures, for instance, are very low, with only $10.48 \%$ of firms in the financial industry declaring innovation research activities. In any case, innovation in the financial industry of CEEC is better than their sustainability orientation. From Table 3, however, we obtain interesting results aligned with this study's goal: innovative firms show higher sustainability orientation. ANOVA tests show, in Table 3, that those firms introducing $R \& D(10.48 \%)$, show higher sustainability orientation (average of all indicators of the variable; accounting for 0.768 ) vs. those that do not (0.09); firms introducing process innovation show a higher sustainability orientation (0.719) vs. those that do not (0.178), although in any case it is a generally lower orientation. All ANOVA comparisons between innovative and noninnovative firms in the financial industry of CEEC show statistically significant results favoring those innovative ones ( $p<0.01$ for all variables, encompassing R\&D, product, process, organizational, marketing and radical innovations). We also found significant differences across countries (for the sake of abbreviation, available upon request). See Table 3.

As aforementioned, 581 firms (36.9\%) reported any innovation activity, in line with the CEEC figures from EURSOTAT, and these innovative firms present higher values for sustainability orientation, ranging from 19\% (improving reputation) or 15\% (costs of energy or materials) to $9 \%$ for "voluntary actions for environmental good practices", showing higher values than the noninnovative ones. See Figure 2.

Overall, in Table 4 we observed at first glance an indication that the firms from the sample present low levels of innovation (e.g., product innovation mean (INNO_PROD) accounts for 0.20, ranging from 0 to 1 ; similarly, process innovation (INNO_PROC) shows 0.19 mean and radical innovation (INNO_RADICAL) presents 0.11, among others) and openness to source external sources of knowledge ( 0.3 on average, ranging the variable from 0 to 7 ). In addition, the correlation matrix shows correlations among the different types of innovation, all significant at $p<0.05$ (5\%). See Table 4 . 
Table 3. Innovation measures by the financial industry in Central and Eastern Europe (CEE) countries.

\begin{tabular}{|c|c|c|c|c|c|}
\hline Sustainability Variable & & Number of Firms & Mean & S.D. & $F($ prob > F $)$ \\
\hline \multirow{2}{*}{ R\&D_INTERNAL } & No & 1409 & 0.090 & 0.809 & \multirow{2}{*}{$\mathrm{F}=116.85^{* * *}$} \\
\hline & Yes & $165(10.48 \%)$ & 0.768 & 1.818 & \\
\hline \multirow{2}{*}{ INNO_PROD } & No & 1261 & 0.179 & 0.515 & \multirow{2}{*}{$\mathrm{F}=231.87^{* * *}$} \\
\hline & Yes & $313(19.88 \%)$ & 0.719 & 1.822 & \\
\hline \multirow{2}{*}{ INNO_PROC } & No & 1272 & 0.178 & 0.549 & \multirow{2}{*}{$\mathrm{F}=240.89^{* * *}$} \\
\hline & Yes & $302(19.18 \%)$ & 0.748 & 1.805 & \\
\hline \multirow{2}{*}{ INNO_ORG } & No & 1178 & 0.208 & 0.429 & \multirow{2}{*}{$\mathrm{F}=231.31^{* * *}$} \\
\hline & Yes & $396(25.15 \%)$ & 0.618 & 1.710 & \\
\hline \multirow{2}{*}{ INNO_MARK } & No & 1202 & 0.168 & 0.593 & \multirow{2}{*}{$\mathrm{F}=157.87^{* * *}$} \\
\hline & Yes & $372(23.63 \%)$ & 0.543 & 1.648 & \\
\hline \multirow{2}{*}{ INNO_RADICAL } & No & 1395 & 0.119 & 0.699 & \multirow{2}{*}{$\mathrm{F}=193.44^{* * *}$} \\
\hline & Yes & $179(11.37 \%)$ & 0.924 & 2.011 & \\
\hline
\end{tabular}

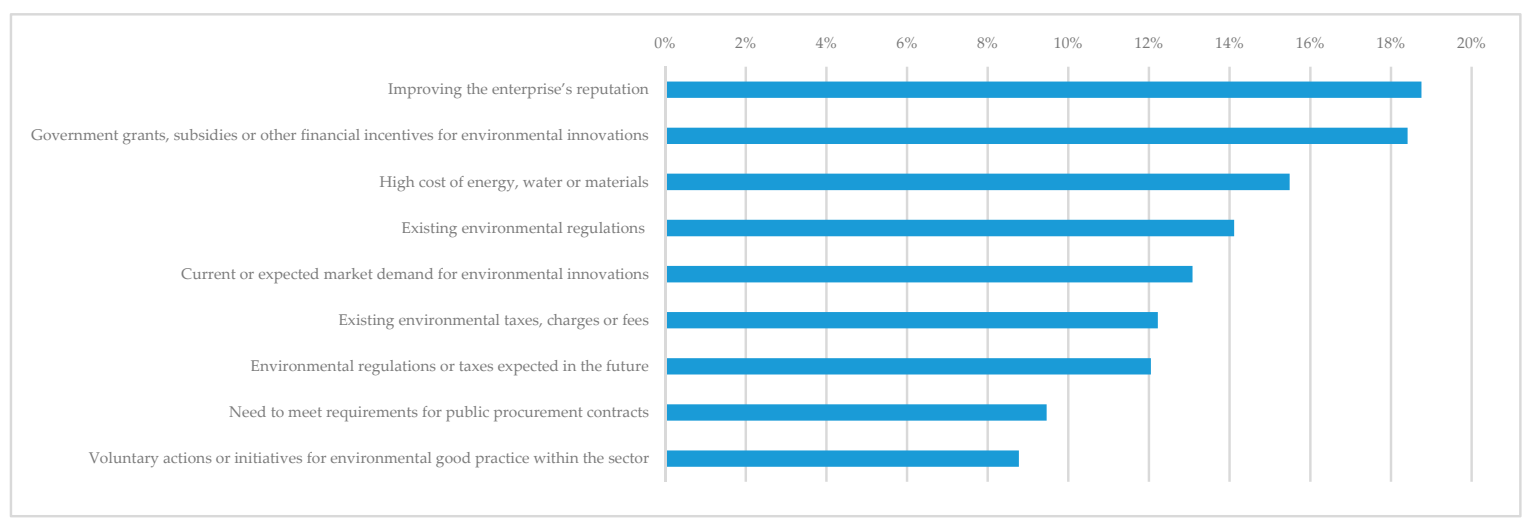

Figure 2. \% of innovative firms that consider that each sustainability-oriented factor is of interest to them (low, medium, high) in driving the enterprise's decisions to introduce innovations with sustainability benefits.

Table 4. Matrix of correlations.

\begin{tabular}{|c|c|c|c|c|c|c|c|c|c|c|c|c|c|}
\hline & & Mean & S.D. & Min & Max & 1 & 2 & 3 & 4 & 5 & 6 & 7 & 8 \\
\hline 1 & SUSTAINABILITY+ & 0 & 1 & & & 1 & & & & & & & \\
\hline 2 & OPENNESS & 0.30 & 0.96 & 0 & 7 & 0.3599 & 1 & & & & & & \\
\hline 3 & INNO_PROD & 0.20 & 0.40 & 0 & 1 & 0.3585 & 0.4998 & 1 & & & & & \\
\hline 4 & INNO_PROC & 0.19 & 0.39 & 0 & 1 & 0.3645 & 0.5188 & 0.6506 & 1 & & & & \\
\hline 5 & INNO_ORG & 0.25 & 0.43 & 0 & 1 & 0.3582 & 0.4174 & 0.5255 & 0.5132 & 1 & & & \\
\hline 6 & INNO_MARK & 0.24 & 0.42 & 0 & 1 & 0.3021 & 0.4125 & 0.5359 & 0.5227 & 0.5666 & 1 & & \\
\hline 7 & INNO_RADICAL & 0.11 & 0.32 & 0 & 1 & 0.3310 & 0.4429 & 0.6689 & 0.5420 & 0.4472 & 0.450 & 1 & \\
\hline 8 & SIZE & 1.53 & 0.71 & 1 & 3 & 0.3024 & 0.3270 & 0.4230 & 0.3614 & 0.372 & 0.3173 & 0.354 & 1 \\
\hline 9 & R\&D_INTERNAL & 0.10 & 0.31 & 0 & 1 & 0.2630 & 0.4443 & 0.4998 & 0.5548 & 0.3704 & 0.3857 & 0.439 & 0.278 \\
\hline
\end{tabular}




\subsection{Econometric Results}

The OLS regression, as mentioned above, presents six models or specifications, also including interaction terms of second and third grade to test the central hypothesis. The linear model utilized is as follows:

$$
\begin{gathered}
\text { SUSTAINABILITY }(\text { factor variable })=f(\text { Intercept }+ \text { Innovation types }+ \text { Openness }(\text { factor variable }) \\
+ \text { Interactions }(\text { second and third order })+\text { Controls }+ \text { Error })
\end{gathered}
$$

Table 5 shows the results of the OLS analysis. In Table 5, we observe that the model adjusts very well, from $\mathrm{R}^{2} 0.23$ to 0.27 , depending on the specification or model. Model 1 only shows control variables, explained below. Focusing on the key variables depicting innovation capabilities, reflected in the successful introduction of product, process, organizational or marketing innovation, as reflected in Model 2, results indicate clearly that those firms introducing process and organizational innovation ( 0.2 and 0.28 , respectively at $p<0.05$ and $p<0.01$ for process and organizational innovations) are positively related to sustainability. Neither product nor marketing is linked to sustainability in the financial industry. Following Yip and Bocken [11], the result is coherent with the financial industry, as most innovations are new processes (e.g., Internet trading platforms, digital branches, robo-advisor or mobile payment) or new organizational activities (e.g., e-statements, internal internet platforms for transactions, etc.). In Model 2, OPENNESS is statistically significant $(0.13$ at $p<0.01)$, meaning that the higher access to external sources of knowledge is also related to a better and higher corporate sustainability orientation. Companies oriented to sustainability require external sources of knowledge, due to the fact that their existing internal capabilities are not sufficiently developed for undertaking new sustainability-oriented purposes, as is stated by De Marchi [34].

Models 3 to 6 account for the configuration of a firm's innovation capability and its influence on corporate sustainability, following our capability-based framework for the creation of superior innovation capabilities from the interaction and mutually reinforcing mechanisms built upon combining different internal and external innovation activities. Thus, Model 3 offers the interaction between internal innovation activities, that is, process and organizational innovation (INNO_PROC x INNO_ORG), showing a statistically significant and positive relationship with corporate sustainability (coefficient, $0.531, p<0.01$ ), capturing the positive effect on sustainability from the joint introduction of process and organizational innovation. As Hervas-Oliver et al. [63] point out, technological process and organizational innovation are difficult to separate, in the sense that these activities usually occur in concurrence [66-68]. Process innovation usually requires organizational innovation, to the extent that these two innovation modes tend to overlap and coincide in many different yet intertwined activities (e.g., [68,69]) This concurrence would serve to reinforce both modes of innovation (e.g., [66]). This organizational integration [68] can be interpreted from the resource-based view and also the complementarities perspective [70].

Similarly, in Model 4, 5 and 6 in Table 5 we also check all different combinations of internal and external innovation activities (Inno_Proc x Openness, 0.150 at $p<0.01$; Inno_Org x Openness, 0.315 at $p<0.01$; and Inno_Proc $x$ Inno_Org x Openness, 0.281 at $p<0.01$, respectively) all of which show positive and statistically significant relationships with sustainability. Put differently, the integration and joint introduction of internal and external innovation activities strengthens and reinforces innovation capability which positively impacts corporate sustainability. Therefore, firms in the financial industry of CEE countries that are innovative and build up superior innovation capabilities by combining internal and external sources of knowledge present higher sustainability orientation. Overall, all results from Table 5 point out that innovation is positively related to sustainability. 
Table 5. OLS model for the relationship between innovation capability and sustainability.

\begin{tabular}{|c|c|c|c|c|c|c|}
\hline SUSTAINABILITY (Factor Variable) & Model 1 & Model 2 & Model 3 & Model 4 & Model 5 & Model 6 \\
\hline \multirow{2}{*}{ INNO_PROD } & & 0.098 & 0.0913 & 0.127 & 0.134 & 0.153 \\
\hline & & 0.0964 & 0.0959 & 0.0973 & 0.0961 & 0.0962 \\
\hline \multirow{2}{*}{ INNO_PROC } & & $0.205^{* *}$ & -0.0533 & 0.135 & $0.229^{* * *}$ & 0.129 \\
\hline & & 0.0879 & 0.110 & 0.0942 & 0.0876 & 0.0885 \\
\hline \multirow[t]{2}{*}{ INNO_ORG } & & $0.286^{* * *}$ & $0.144^{* *}$ & $0.288^{* * *}$ & $0.196^{* * *}$ & $0.228^{* * *}$ \\
\hline & & 0.0697 & 0.0787 & 0.0696 & 0.0725 & 0.0701 \\
\hline \multirow[t]{2}{*}{ INNO_MARK } & & 0.0692 & 0.099 & 0.0722 & 0.0756 & 0.081 \\
\hline & & 0.0718 & 0.0719 & 0.0717 & 0.0714 & 0.0712 \\
\hline \multirow[t]{2}{*}{ INNO_PROC_x_INNO_ORG } & & & $0.531^{* * *}$ & & & \\
\hline & & & 0.139 & & & \\
\hline \multirow{2}{*}{ INNO_PROC_x_OPENNESS } & & & & $0.150 * *$ & & \\
\hline & & & & 0.0729 & & \\
\hline \multirow{2}{*}{ INNO_ORG_x_OPENNESS } & & & & & $0.315^{* * *}$ & \\
\hline & & & & & 0.0747 & \\
\hline \multirow{2}{*}{$\begin{array}{c}\text { INNO_PROC_x_INNO_ORG_ } \\
\text { x_OPENNESS }\end{array}$} & & & & & & $0.281^{* * *}$ \\
\hline & & & & & & 0.057 \\
\hline \multirow{2}{*}{ INNO_RADICAL } & $0.641^{* * *}$ & $0.382 * * *$ & $0.359^{* * *}$ & $0.385^{* * *}$ & $0.384^{* * *}$ & $0.388^{* * *}$ \\
\hline & 0.0873 & 0.105 & 0.105 & 0.105 & 0.104 & 0.104 \\
\hline \multirow{2}{*}{ OPENNESS } & $0.189^{* * *}$ & $0.135^{* * *}$ & $0.119^{* * *}$ & 0.0148 & $-0.139 *$ & -0.0631 \\
\hline & 0.0318 & 0.0327 & 0.0328 & 0.0671 & 0.0727 & 0.0517 \\
\hline \multirow{2}{*}{ SIZE } & $0.191^{* * *}$ & $0.134^{* * *}$ & $0.126^{* * *}$ & $0.137^{* * *}$ & $0.129^{* * *}$ & $0.133^{* * *}$ \\
\hline & -0.0361 & -0.0368 & -0.0367 & 0.0368 & 0.0366 & 0.0365 \\
\hline \multirow{2}{*}{ R\&D_INTERNAL } & 0.0467 & -0.0908 & -0.098 & -0.0882 & -0.074 & -0.0809 \\
\hline & 0.0982 & 0.101 & 0.100 & 0.101 & 0.100 & 0.0998 \\
\hline COUNTRY_DUMMIES & YES & YES & YES & YES & YES & YES \\
\hline \multirow[t]{2}{*}{ Intercept } & $-0.423^{* * *}$ & $-0.418 * * *$ & $-0.389 * * *$ & $-0.421 * * *$ & $-0.403 * * *$ & $-0.408^{* * *}$ \\
\hline & 0.0642 & 0.0639 & 0.064 & 0.0638 & 0.0636 & 0.0633 \\
\hline Observations & 1574 & 1574 & 1574 & 1574 & 1574 & 1574 \\
\hline R-squared & 0.236 & 0.259 & 0.268 & 0.262 & 0.269 & 0.273 \\
\hline Prob $>F$ & 0.000 & 0.000 & 0.000 & 0.000 & 0.000 & 0.000 \\
\hline F & 33.69 & 28.53 & 28.0 & 27.17 & 28.24 & 28.76 \\
\hline
\end{tabular}

As regards control variables, we observed in Model 1, as well as other models, that R\&D is not statistically significant. This means that the intensity of the investment in internal innovation activities does not drive sustainability. This result is expected as the financial industry is not an intensive R\&D industry in the CEEC. It may explain innovation but is not connected to sustainability. Then, we also observed that Radical variable (Model 1 coefficient 0.6 and Model 2, 0.38, both at $p<0.01$ ) shows that the most radical innovations are linked to higher corporate sustainability orientation, at $p<0.01$. This result is explained by the fact that the most innovative firms engage in radical innovations, and this is connected to sustainability. Control variables also indicate that the country of origin matters to achieve more or less corporate sustainability performance and the SIZE is positive; the larger the firm the higher the corporate sustainability orientation, probably because of the greater available resources to invest in innovation. See Table 5.

Table 5 confirms that in the financial and banking industry, the composite indicator of corporate sustainability performance is positively related to innovation. These results confirm extant literature and contribute by providing a different innovation capability-based framework and ample and robust empirical support through CIS data. Thus, our study does contribute to the innovation and 
sustainability intersection in the financial industry $[1,11,38])$ in CEE countries [12]. According to these results, the hypothesis is confirmed and this study's core message is that best in class innovators are also best performers of corporate sustainability, despite observing that the financial industry in CEEC is poorly connected to sustainability.

\section{Discussion and Conclusions}

When referring to the link between innovation and sustainability, most efforts are focused on manufacturing (e.g., [33]), there being a very limited literature on that topic for the case of the financial industry. This under-researched topic, in no small part, is due to the wrongly assumed limited environmental impact of the industry [1]. In this study we attempt to contribute to analysis of the intersection of sustainability-oriented innovation in the financial industry and the specific context of analysis catching-up and CEE countries, as both topics are under-researched. Thus, our goal consists of assessing whether innovation is linked to corporate sustainability orientation in the financial industry of CEE countries, presenting a framework based on a capability-based view [18] and innovation studies (e.g., [41]) from which to address sustainable-oriented innovation.

Empirically, this study utilized data from CIS (2012-2014), encompassing innovation and sustainability in 11 countries of Europe and addressing 1574 firms. Overall, this study contributes by adding, specifically: (i) the study of sustainability-oriented innovation in the financial industry, (ii) the study of catching-up countries of CEE, (iii) a capability framework from which to interpret the link between innovation and sustainability and, (iv) the utilization of a database (CIS from EUROSTAT) not yet utilized for the financial industry in the topic, nor in the realm of catching-up and CEEC. To the best of our knowledge, this present study is the first encompassing the combination of those related lines of inquiry.

Specifically, the results show that catching-up and CEE countries present poor innovation and sustainability orientation, at least compared to other Western countries. Despite the low orientation on both dimensions, results point out that innovation capability built upon the joint introduction of process and organizational innovation is positively related to sustainability-orientation in the financial industry of CEE countries. Put differently, the most innovative companies are also the ones with higher sustainability orientation. The joint introduction of different internal innovation activities, such as those related to process and organizational, as well as the reinforcing combination of internal and external sources of knowledge (e.g., [16,34]), configure a firm's innovation capability that beyond innovation outcomes can also positively drive corporate sustainability. Sustainability requires integrating internal and external innovation activities such as new digitalization of internal documents, electronic writing pads for transactions, e-learning, tele-conferencing and double-sided printing or mobile banking, among many others. Some of them can be implemented by internal activities and others require external support from suppliers, consultants, etc.

Theoretically, this study shows how the commitment to building innovation capabilities, through the combination of internal and external activities to innovate, facilitates innovation and sustainability. This learning process is well documented in the learning literature [17] and the management strand $[16,52]$ and it is also reinforced by the resource-based view of the firm (e.g., $[18,57,61])$ and the dynamic capabilities perspective [19]. This integrated body of literature cross-fertilizes, from different perspectives, a capability formation process. In short, this school of thought claims that the combination of knowledge, in a unique way, configures a firm's capability to improve competitive advantage and performance. As shown in our results, the combination of innovative activities, both internal and external, created a superior and unique capability to innovate that leads to superior corporate sustainability.

Our results also contribute to the sustainability literature $[4,9,38]$ by extending knowledge on those institutionally-different countries of $\mathrm{CEE}$, giving response to the different claims of further research on innovation in catching-up countries [14], especially in the financial industry [12] and on sustainability $[12,49]$ where research is scant or even inexistent. In addition, our results add more 
evidence to sustainability-oriented innovation that can also be utilized in other industries such as manufacturing [35] and also contribute to general sustainability-dedicated studies in the financial industry [71]).

These results present some implications for policymakers, managers and scholars. According to the results, managers in the financial industry need to focus on process and organizational innovation if they want to improve corporate sustainability, recognizing the impact that innovation can exert on sustainability and its social, environmental and governance dimensions [62]. Corporate sustainability requires the acceptance of the fact that the learning process to innovate and build up innovation capabilities is also a precondition from which to orient companies toward sustainability practices: innovation is a leverage of sustainability. Thus, a better innovation capability drives better sustainability-based performance related to different fronts, such as those related to improving a company's reputation, introducing environmental good practices within the industry or reducing energy and materials, among others.

For scholars, this study presents different implications. First and foremost, it is important to relate innovation and sustainability to the financial industry, as it is an industry with ample opportunities to contribute to sustainability practices and processes. Focusing on CEEC also represents an opportunity to expand knowledge on different institutional specificities that can contribute to enriching our knowledge on sustainability-oriented innovation: we need to move the analysis beyond the Western reality and embrace new contexts such as catching-up and those at CEEC. For theorizing, RBV constitutes an interesting framework from which to understand sustainability-oriented innovation, as it addresses the fundamentals of a firm's capability to innovate and also to seek sustainability goals. Another important matter is the results obtained in the analysis: in the financial industry, process and organizational innovation drive sustainability, not only innovation in general. It is also interesting to use the support of external sources of knowledge, in order to fit firms' capabilities into the new requirements demanded by the sustainability processes.

For policymakers, in order to best capture innovation in the financial industry, policymakers need to be aware of the differing investments in internal and external activities to innovate and how they are positively related to corporate sustainability. Having said that, it is also important that the stimulation of innovation is a proven way to achieve better sustainability. For this reason, policymakers need to incentivize innovation in the industry to stimulate sustainability. Having said that, it is also important to recognize the fact that catching-up and CEE countries present poor levels of innovation due to thin innovation systems (e.g., [14]) and similar sustainability orientation (e.g., [12,13]). Further incentives and policies should consider this reality and measures are needed to promote and stimulate a more proactive adoption and orientation toward sustainability practices.

Beyond the theoretical discussion, it is also important to notice the robust and ample coverage of our sample, representing a strong point in our analysis: 1574 firms across 11 European countries. Thus, this study also shows how useful the use of the CIS database for measuring innovation and sustainability in the banking industry can be, opening new research avenues for scholars to test other related questions. Our study is limited by the type of data used and a short time window covering just three years. Additionally, for scholars, it is also interesting to visualize new sources of data (CIS database from EUROSTAT) for working with innovation (e.g., [72]) and sustainability in the financial industry in different yet related questions, such as the barriers that hamper innovation and the consequent effect on sustainability. Finally, future studies may focus on specific innovations (digital, life-work balance, etc.) and their impacts on sustainability in the financial industry.

Author Contributions: Conceptualization, F.S.-R. and J.-L.H.-O.; methodology, F.S.-R., S.E.-M. and R.R.-A.; writing-original draft preparation, J.-L.H.-O., F.S.-R., S.E.-M. and R.R.-A.; funding acquisition, J.-L.H.-O. All authors have read and agreed to the published version of the manuscript.

Funding: This research was funded by MINISTRY OF SCIENCE, INNOVATION AND UNIVERSITY, grant number RTI2018-095739-B-100. 
Acknowledgments: We acknowledge EUROSTAT data support. Francisca Sempere-Ripoll thanks. Davide Parrilli from the Faculty of Management at Bournemouth University and "Salvador Madariaga Program" funded by the Spanish Ministry Science, Innovation and Universities (ref: PRX19/00538).

Conflicts of Interest: The authors declare no conflict of interest.

\section{References}

1. Forcadell, F.J.; Aracil, E. Can multinational companies foster institutional change and sustainable development in emerging countries? A case study. Bus. Strateg. Dev. 2019, 2, 91-105. [CrossRef]

2. Amore, M.D.; Schneider, C.; Žaldokas, A. Credit supply and corporate innovation. J. Financ. Econ. 2013, 109, 835-855. [CrossRef]

3. Hsu, P.H.; Tian, X.; Xu, Y. Financial development and innovation: Cross-country evidence. J. Financ. Econ. 2014, 112, 116-135. [CrossRef]

4. Laukkanen, T. Consumer adoption versus rejection decisions in seemingly similar service innovations: The case of the Internet and mobile banking. J. Bus. Res. 2016, 69, 2432-2439. [CrossRef]

5. Epstein, M.J.; Roy, M.-J. Improving sustainability performance: Specifying, implementing and measuring key principles. J. Gen. Mana. 2003, 29, 15-31. [CrossRef]

6. Freeman, R.E. Stakeholder Management: Framework and Philosophy; Pitman: Mansfield, MA, USA, 1984.

7. Simpson, G.; Kohers, T. The link between corporate social and financial performance: Evidence from the banking industry. J. Bus. Ethics 2002, 35, 97-109. [CrossRef]

8. Wu, M.-W.; Shen, C.-H. Corporate social responsibility in the banking industry: Motives and financial performance. J. Bank. Financ. 2013, 37, 3529-3547. [CrossRef]

9. Esteban-Sanchez, P.; de la Cuesta-Gonzalez, M.; Paredes-Gazquez, J.D. Corporate Social Performance and its relation with Corporate Financial Performance: International evidence in the banking industry. J. Clean. Prod. 2017, 162, 1102-1110. [CrossRef]

10. Adams, R.; Jeanrenaud, S.; Bessant, J.; Denyer, D.; Overy, P. Sustainability-oriented innovation: A systematic review. Int. J. Manag. Rev. 2016, 18, 180-205. [CrossRef]

11. Yip, A.W.H.; Bocken, N.M.P. Sustainable business model Archetypes for the banking industry. J. Clean. Prod. 2018, 174, 150-169. [CrossRef]

12. Fijałkowska, J.; Zyznarska-Dworczak, B.; Garsztka, P. Corporate social-environmental performance versus financial performance of banks in central and eastern European countries. Sustainability 2018, 10, 772. [CrossRef]

13. Furrer, O.; Egri, C.P.; Ralston, D.A.; Danis, W.; Reynaud, E.; Naoumova, I.; Molteni, M.; Starkus, A.; Darder, F.L.; Dabic, M. Attitudes toward corporate responsibilities in Western Europe and in Central and East Europe. Manag. Int. Rev. 2010, 50, 379-398. [CrossRef]

14. Castellacci, F.; Archibugi, D. The technology clubs: The distribution of knowledge across nations. Res. Policy 2008, 37, 1659-1673. [CrossRef]

15. Cai, W.G.; Zhou, X.L. On the drivers of eco-innovation: Empirical evidence from China. J. Clean. Prod. 2014, 79, 239-248. [CrossRef]

16. Cainelli, G.; De Marchi, V.; Grandinetti, R. Does the development of environmental innovation require different resources? Evidence from Spanish manufacturing firms. J. Clean. Prod. 2015, 94, 211-220. [CrossRef]

17. Awaysheh, A.; Heron, R.; Perry, T.; Wilson, J. On the Relation between corporate social responsibility and Financial Performance. Strateg. Manag. J. 2020. [CrossRef]

18. Barney, J.B. The resource-based theory of the firm. Organ. Sci. 1996, 7, 469-593. [CrossRef]

19. Teece, D.J.; Pisano, G.; Shuen, A. Dynamic capabilities and strategic management. Strateg. Manag. J. 1997, 18, 509-533. [CrossRef]

20. Park, E.; Kim, K.J.; Kwon, S.J. Corporate social responsibility as a determinant of consumer loyalty: An examination of ethical standard, satisfaction, and trust. J. Bus. Res. 2017, 76, 8-13. [CrossRef]

21. Bansal, P.; Song, H. Similar but not the same: Differentiating corporate sustainability from corporate responsibility. Acad. Manag. Ann. 2017, 11, 105-149. [CrossRef]

22. Bocken, N.; Short, S.W.; Rana, P.; Evans, A. A literature and practice review to develop sustainable business model archetypes. J. Clean Prod. 2014, 65, 42-56. [CrossRef] 
23. Orlitzky, M.; Schmidt, F.L.; Rynes, S.L. Corporate social and financial performance: A meta-analysis. Organ. Stud. 2003, 24, 403-441. [CrossRef]

24. Margolis, J.D.; Elfenbein, H.; Walsh, J.P. Does it Pay to be Good? A Meta-Analysis and Redirection of Research on the Relationship between Corporate Social and Financial Performance. In Working Paper; Ross School of Business: Ann Arbor, MI, USA, 2007.

25. Surroca, J.A.; Aguilera, R.V.; Desender, K.; Tribo, J.A. Is managerial entrenchment always bad and corporate social responsibility always good? A cross-national examination of their combined influence on shareholder value. Strateg. Manag. J. 2020. [CrossRef]

26. Luo, X.; Du, S. Exploring the relationship between corporate social responsibility and firm innovation. Market. Lett. 2015, 26, 703-714. [CrossRef]

27. Horbach, J. Determinants of environmental innovation. New evidence from German panel data sources. Res. Policy 2008, 37, 163-173. [CrossRef]

28. Lu, B.; Li, B.; Wang, L.; Yang, J.; Liu, J.; Wang, X.V. Reusability based on Life Cycle Sustainability Assessment: Case Study on WEEE. Procedia CIRP 2014, 15, 473-478. [CrossRef]

29. Urban, M.A.; Wójcik, D. Dirty banking: Probing the gap in sustainable finance. Sustainability 2019, 11, 1745. [CrossRef]

30. Chih, H.L.; Chih, H.H.; Chen, T.Y. On the determinants of corporate social responsibility: International evidence on the financial industry. J. Bus. Ethics 2010, 93, 115-135. [CrossRef]

31. Wang, J.; Wang, Y.; Li, S.C.; Qin, D.H. Climate adaptation, institutional change, and sustainable livelihoods of herder communities in northern Tibet. Ecol. Soc. 2016, 21, 5. [CrossRef]

32. Lauesen, L.M. CSR in the aftermath of the financial crisis. Soc. Respon J. 2013, 9, 641-663.

33. Hurely, J.A.; Green, T.A.; Gouge, D.H.; Bruns, Z.T.; Stock, T.; Bra-Band, L.; Murray, K.; Westinghouse, C.; Ratcliffe, S.T.; Pehlman, D.; et al. Regulating pesticide use in United States schools. Am. Entomol. 2014, 60, 105-111. [CrossRef]

34. Di Marchi, V. Environmental innovation and R\&D cooperation: Empirical evidence from Spanish manufacturing firms. Res. Policy 2012, 41, 614-623.

35. Kemp, R.; Olsthoorn, X.; Oosterhuis, F. Supply and demand factors of Cleaner technologies: Some empirical evidence. Environ. Resour. Econ. 1992, 2, 615-634.

36. Orsatti, G.; Quatrato, F.; Pezzoni, M. The antecedents of green technologies: The role of team-level recombinant capabilities. Res. Policy 2019, 49, 103919. [CrossRef]

37. Bossink, B.A. Leadership for sustainable innovation. Int. J. Tech. Manag. Sustain. Dev. 2007, 6, 135-149. [CrossRef]

38. Zhao, Q.; Tsai, P.; Wang, J. Improving financial service innovation strategies for enhancing china's banking industry competitive advantage during the fintech revolution: A Hybrid MCDM model. Sustainability 2019, 11, 1419. [CrossRef]

39. Apanasovich, N.; Alcalde Heras, H.; Parrilli, M.D. The impact of business innovation modes on SME innovation performance in post-Soviet transition economies: The case of Belarus. Technovation 2016, 57-58, 30-40. [CrossRef]

40. Szczygielski, K.; Grabowski, W.; Pamukcu, M.T.; Tandogan, V.S. Does government support for private innovation matter? Firm-level evidence from two catching-up countries. Res. Policy 2017, 46, 219-237. [CrossRef]

41. Laursen, K.; Salter, A.J. Open for innovation: The role of openness in explaining innovation performance among UK manufacturing firms. Strateg. Manag. J. 2006, 27, 131-150. [CrossRef]

42. Evangelista, R.; Vezzani, A. The economic impact of technological and organizational innovations. A firm-level analysis. Res. Policy 2010, 39, 1253-1263. [CrossRef]

43. Escribano, A.; Fosfuri, A.; Tribó, J.A. Managing external knowledge flows: The moderating role of absorptive capacity. Res. Policy 2009, 39, 96-105. [CrossRef]

44. Heidenreich, E. Spaces of flow as technical and cultural mediators between society and nature. Environ. Dev. Sustain. 2009, 11, 1145-1154. [CrossRef]

45. Rammer, C.; Czarnitzki, D.; Spielkamp, A. Innovation Success of Non-R\&D-Performers: Substituting Technology by Management in SMEs. Small Bus. Econ. Group 2009, 33, 35-58. 
46. Grillitsch, M.; Hansen, T. Green industry development in different types of regions. Eur. Plan. Stud. 2019, 27, 2163-2183. [CrossRef]

47. Heyman, F.; Persson, L.; Andersson, F. Has the Swedish business sector become more entrepreneurial than the US business sector? Res. Policy 2019, 48, 1809-1822. [CrossRef]

48. Isaksen, A.; Trippl, M. Innovation in Space: The Mosaic of Regional Innovation Patterns. Oxf. Rev. Econ. Policy 2007, 33, 122-140. [CrossRef]

49. Dyduch, J.; Krasodomska, J. Determinants of Corporate Social Responsibility Disclosure: An Empirical Study of Polish Listed Companies. Sustainability 2017, 9, 1934. [CrossRef]

50. Campbell, J.L. Why would corporations behave in socially responsible ways? An institutional theory of corporate social responsibility. Acad. Manag. Rev. 2007, 32, 946-967. [CrossRef]

51. Cassiman, B.; Veugelers, R. In search of complementarity in innovation strategy: Internal R\&D and external knowledge acquisition. Manag. Sci. 2006, 52, 68-82.

52. Penrose, E.T. The Theory of the Growth of the Firm, 1st ed.; Basil Blackwell: Oxford, UK, 1959.

53. Cohen, W.M.; Levinthal, D.A. Absorptive capacity: A new perspective on learning and innovation. Admin. Sci. Quart. 1990, 35, 128-152. [CrossRef]

54. Chesbrough, H. Open Innovation: The New Imperative for Creating and Profiting from Technology; Harvard Business School Press: Boston, MA, USA, 2003.

55. Volberda, H.W.; Foss, N.J.; Lyles, M.A. Absorbing the notion of absorptive capacity: How to realize its potential in the organization field. Organ. Sci. 2010, 21, 931-951. [CrossRef]

56. Hervas-Oliver, J.L.; Sempere-Ripoll, F.; Rojas Alvarado, R.; Estelles-Miguel, S. Beyond product innovation: Deciphering process-oriented innovators, complementarities and performance effects. Technol. Anal. Strateg. 2018, 30, 582-595. [CrossRef]

57. Rivkin, J.W. Imitation of complex strategies. Manag. Sci. 2000, 46, 824-844. [CrossRef]

58. Hervas-Oliver, J.L.; Albors-Garrigos, J.; Gil-Pechuan, I. Making sense of innovation by R\&D and non-R\&D innovators in low technology contexts: A forgotten lesson for policymakers. Technovation 2011, 31, 427-446.

59. Clausen, T.H.; Korneliussen, T.; Madsen, E.L. Modes of innovation, resources and their influence on product innovation: Empirical evidence from RD active firms in Norway. Technovation 2013, 33, 225-233. [CrossRef]

60. Marzucchi, A.; Montresor, S. Forms of knowledge and eco-innovation modes: Evidence from Spanish manufacturing firms. Ecol. Econ. 2017, 131, 208-221. [CrossRef]

61. Stieglitz, N.; Heine, K. Innovations and the role of complementarities in a strategic theory of the firm. Strateg. Manag. J. 2007, 28, 1-15. [CrossRef]

62. Del Río, P.; Morán, M.Á.T.; Albinana, F.C. Analysing the determinants of environmental technology investments. A panel-data study of Spanish industrial sectors. J. Clean. Prod. 2011, 19, 1170-1179. [CrossRef]

63. Hervas-Oliver, J.L.; Sempere-Ripoll, F.; Boronat-Moll, C. Process innovation strategy in SMEs, organizational innovation and performance: A misleading debate? Small Bus Econ. 2014, 43, 873-886. [CrossRef]

64. Leiponen, A.; Helfat, C.E. Innovation objectives, knowledge sources, and the benefits of breadth. Strateg. Manag. J. 2010, 31, 224-236. [CrossRef]

65. Bencivenga, V.R.; Smith, B.D. Financial intermediation and endogenous growth. Rev. Econ. Stud. 1991, 58, 195-209. [CrossRef]

66. Damanpour, F. Footnotes to research on management innovation. Organ. Stud. 2014, 35, 1265-1285. [CrossRef]

67. Edquist, C.; Hommen, L.; McKelvey, M. Innovation and Employment: Process versus Product Innovation; Edward Elgar Publishing: Cheltenham, UK, 2011; Volume 214.

68. Ettlie, J.E.; Reza, E.M. Organizational integration and process innovation. Acad. Mana. J. 1992, 35, $795-827$.

69. Womach, J.P.; Jones, D.; Roos, D. The Machine That Changed the World; Rawson-Macmillan: New York, NY, USA, 1990.

70. Milgrom, P.; Roberts, J. Complementarities and fit: Strategy structure and organizational change in manufacturing. J. Account. Econ. 1995, 19, 179-208. [CrossRef] 
71. Scholtens, B. Corporate social responsibility in the international banking industry. J. Bus. Ethics 2009, 86, 159-175. [CrossRef]

72. Hervas-Oliver, J.L.; Sempere-Ripoll, F.; Estelles-Miguel, S.; Rojas-Alvarado, R. Radical vs incremental innovation in Marshallian Industrial Districts in the Valencian Region: What prevails? Eur. Plan. Stud. 2019, 27, 1924-1939. [CrossRef] 